\title{
Strontium Isotope Ratios as a Tool for the Origin of Barite Mineralization of Marsis and Lefan Deposits/ Northeast Zakho / Iraq
}

\author{
Faraj H. Tobia \\ Department of Geology \\ College of Science \\ University of Salah Alddin
}

(Received 7/1/2010, Accepted 18/3/2010)

\begin{abstract}
Veins, vienlets, pockets and cavity- filling deposits of barite are found to be associated with Upper Jurassic Formations (Marsis deposit) and Upper Cretaceous Bekhme Formation (Lefan deposit). The strontium isotope ratios of barite are presented here and the data are used to understand the source and origin of barite. The relation of barite mineralization with carbonate host rocks reveals a stratabound epigenetic origin. The obtained ${ }^{87} \mathrm{Sr} /{ }^{86} \mathrm{Sr}$ ratios range from 0.708226 to 0.708452; these values reveal the possibility of involvement of crustal $\mathrm{Sr}$ in the deposition of Marsis and Lefan barite. Isotopic data reveal that strontium in barite was derived from coeval seawater of Late Cretaceous and other processes like mixing of low temperature hydrothermal solution derived from the crust that was rich in radiogenic ${ }^{87} \mathrm{Sr}$.

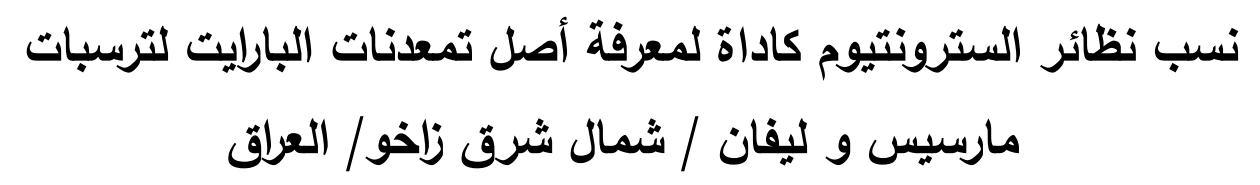

$$
\text { فرج حبيب طوييا }
$$
\end{abstract}




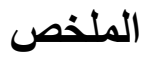

تتواجد ترسبات البارايت على شكل عروق وعريقات وجيوب مائلة للفراغات مترافقة لتكاوين الجوراسي

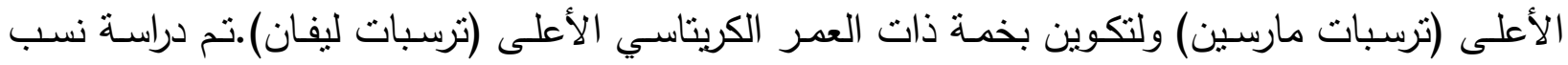
نظائر السترونتيوم لاستخدامها في فهم مصدر واصل ترسبات البارايت في منطقتي الدراسة.

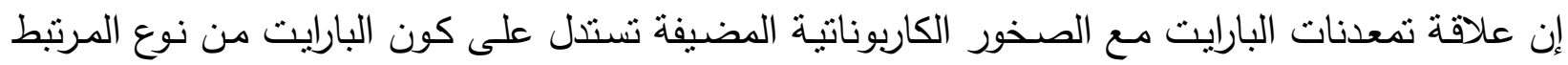

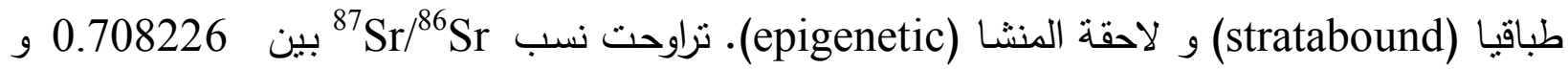
0.708452 و تدل هذه القيم على احتمال مشاركة القشرة الأرضية في تكوين ترسبات البارايت لمنطقتي مارسين و ليفـان. تثـير معلومـات النظـائر أن السـترونتيوم في البارايت مشتق مـن ميـاه البحر للعصر

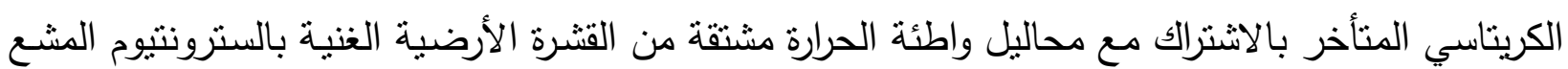
${ }^{87} \mathrm{Sr}$

\section{INTRODUCTION}

It is well understood that strontium isotope geochemistry of barite provides an insight to the source and the origin of this mineral (Sharma et al., 2003; Fei et al., 2004; Ayuso et al., 2004).

Strontium can enter the lattice of mineral structures such as calcite, fluorite, gypsum, and barite. it is similar to $\mathrm{Ba}$ and $\mathrm{Ca}$ in geochemical characteristics. Strontium isotope composition of these minerals, when formed in equilibrium with seawater directly records the strontium isotope composition of the coeval seawater. The main assumptions for the use of ${ }^{87} \mathrm{Sr} /{ }^{86} \mathrm{Sr}$ ratio as tracer of various geological processes is that at any given time the oceans contain well mixed $\mathrm{Sr}$ isotopes and that strontium isotope ratio of oceans changed during geological evolution. These changes have been induced by variations in the relative inputs of $\mathrm{Sr}$ to the oceans after decay of $\mathrm{Rb}$ (Barbieri et al., 1998).

From meteorite analysis (where $\mathrm{Rb}$ is almost absent), the earth's primordial $\mathrm{Sr}$ have an initial ${ }^{87} \mathrm{Sr}{ }^{86} \mathrm{Sr}$ ratio of 0.699 at the birth of the earth (4.5 B.Y. ago). The mantle contains a small amount of $\mathrm{Rb}$, and as a result its ${ }^{87} \mathrm{Sr} /{ }^{86} \mathrm{Sr}$ ratio has grown from 0.699 to about 0.7037 over the course of geological time. The average ${ }^{87} \mathrm{Sr} /{ }^{86} \mathrm{Sr}$ of the earth crust has been growing through geological time due to the enrichment of $\mathrm{Rb}$ content, reaching an average value of about 0.719 at the present day. On the other hand, sedimentary rocks have much higher ${ }^{87} \mathrm{Sr} /{ }^{86} \mathrm{Sr}$ ratios because of the huge amount of rubidium $\mathrm{Rb}$ in the earth is concentrated in the crust (Hall, 1987). 


\section{GEOLOGICAL SETTING}

Two areas containing barite deposits are studied. These are Marsis and Lefan located Northeast of Zakho city, within the Northern Thrust Zone, North of Iraq (Fig.1). These deposits are hosted within carbonate rocks. The field observations show that the mineral deposits in Marsis are hosted in Units B and C of Upper Jurassic rocks (Al-Ka'aby and Al-Azawi, 1992). While they embedded within Bekhme Formation (Upper Cretaceous) partially extending into Shiranish Formation age ( in Lefan area) (Al-Ka'aby and Al-Azawi, 1992; Awadh, 2006).

Marsis area is about $25 \mathrm{~km}$ to the Northeast of Zakho city. The area is highly mountainous and characterized by the presence of cliffs and steep slopes. The area is crossed by three main valleys that intersect to form Basa Agha valley which flows to the west.

The stratigraphic section in Marsis area consists mainly of carbonate rocks of about $590 \mathrm{~m}$ thick representing geological time from Upper Jurassic to Upper Cretaceous. There is a large variation in the thickness due to tectonic activities during deposition (Ma'ala et al., 1990).

The Jurassic sediments about $63 \mathrm{~m}$ thick crop out in the northern block of a major reverse fault (Fig. 1). The distinction between the Upper Jurassic sediments in this area is very difficult due to dolomitization of most fossils. Therefore, AlKa'aby and Al-Azawi (1992) subdivided these rocks into three units according to field observations (Fig. 2). Unit A is the older unit composed of dolomitic rocks, gray to dark gray in color, fine crystalline, very hard and highly resistant to the erosion that forms a cliff and nearly vertical slopes. Unit B is olive green, recrystallized and brecciated dolomitic limestone And characterized by the presence of vienlets and pockets of barite with some voids. Unit $\mathrm{C}$ includes dark gray to black dolomitic limestone, coarse grained, sandy texture, with voids, easily disaggregates, and forms gentle slopes. Predominantly, the fractures and voids are filled with barite.

Lefan location is about $5 \mathrm{~km}$ to the south of Marsis location (Fig. 1). The mineralization is located within Bekhme Formation and partially extends into Shiranish Formation. Bekhme Formation is composed of bituminous secondary dolomite, replacing organic detrital limestone in its upper part, and reefal detrital limestone in the middle part, with basal breccia conglomerate in the lower part (Jassim and Goff, 2006). Shiranish Formation conformably overlies the Bekhme Formation, composed of thin bedded argillaceous limestones (locally dolomitic) overlain by blue pelagic marls (Bellen et al., 1959; Jassim and Goff, 2006). 


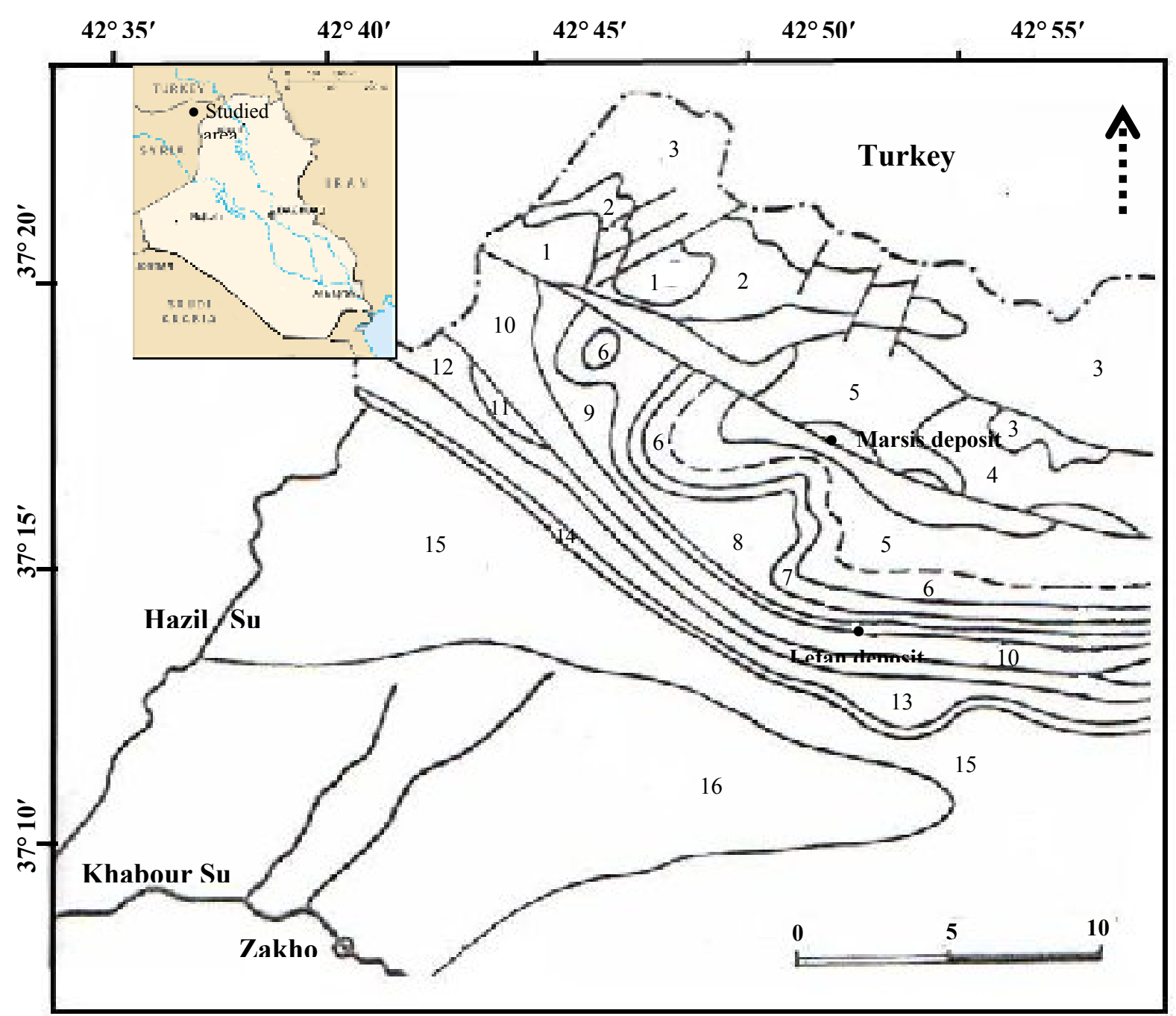

\begin{tabular}{|c|l|c|l|}
\hline 17 & U. Bakhtiari (Pliocene- Pliestocene) & $\wedge$ & Qamchuqa (M. Cretaceous) \\
\hline 10 & U. Faris (U. Miocene) & $\checkmark$ & Sarmord Formation (L. Cretaceous) \\
\hline $1 \varepsilon$ & Anah Formation (Oligocene) & $\checkmark$ & M.\& U. Jurassic Formations \\
\hline $1 r$ & Pila Spi (M.- U. Eocene) & 0 & Sehkaniyan and Sarki Formations (L. Jurassic) \\
\hline $1 r$ & Gercus Formation (L. Eocene) & $\varepsilon$ & Kurra Chine Formations (U.Triassic) \\
\hline 11 & Kolosh Formation (Pliocene) & $r$ & Serwan Formation (Triassic) \\
\hline 1. & Shiranish Formation (U. Cretaceous) & $r$ & Chia Zairi Formation (U.Permian) \\
\hline 9 & Aqra/Bekhme (U. Cretaceous) & 1 & Ora Formation (L. Carboniferous) \\
\hline
\end{tabular}

Fig. 1: Location and geological map of NE Zakho, (McCarthy and Smith, 1954). 


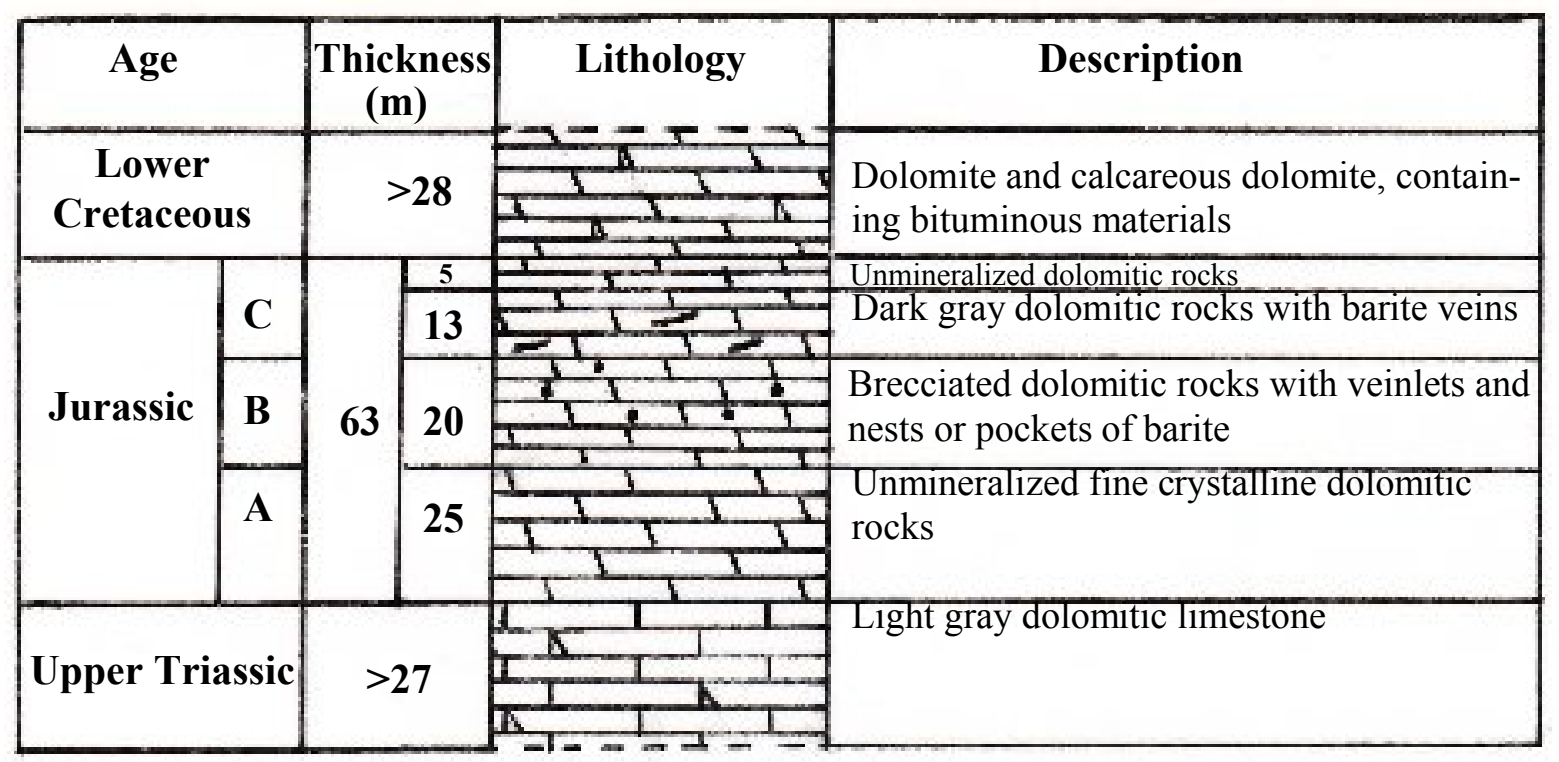

Fig.2: Typical columnar section for barite deposits in Marsis location/ Zakho (Al-Ka'aby and Al-Azawi, 1992).

\section{SAMPLING AND ANALYTICAL METHOD}

Four samples of barite which were collected from veins in Marsis (2 samples) and cavities filling in Lefan (2 samples) deposits, analyzed for ${ }^{87} \mathrm{Sr} /{ }^{86} \mathrm{Sr}$ ratios and the results are presented in Table 1.

Table 1: Strontium Isotope Ratios of Marsis and Lefan Barite Deposits.

\begin{tabular}{|c|c|c|c|}
\hline Locality & Sample & ${ }^{\mathbf{8 7}} \mathbf{S r} /{ }^{\mathbf{8 6}} \mathbf{S r}$ & $\mathbf{1 \delta}$ \\
\hline Marsis & M1 & 0.708246 & \pm 0.000004 \\
\hline Marsis & M2 & 0.708272 & \pm 0.000007 \\
\hline Lefan & L1 & 0.708226 & \pm 0.000004 \\
\hline Lefan & L2 & 0.708452 & \pm 0.000004 \\
\hline
\end{tabular}

The Sr isotope composition was analyzed in Swedish Museum of Natural History/ Laboratory for Isotope Geology. Sr isotope ratio was measured on a Thermo Scientific TRITON Thermal Ionization Mass Spectrometer (TIMS). Measured ${ }^{87} \mathrm{Sr}$ intensities were corrected for $\mathrm{Rb}$ interference using ${ }^{87} \mathrm{Rb} /{ }^{85} \mathrm{Rb}=$ 0.38600 and ratios were reduced using the exponential fractionation law and ${ }^{88} \mathrm{Sr} /{ }^{86} \mathrm{Sr}=8.375209$. The external precision for ${ }^{87} \mathrm{Sr} /{ }^{86} \mathrm{Sr}$ as judged from running NBS987 standard is $16 \mathrm{ppm}(\mathrm{n}=33)$. No accuracy correction had to be made, while 
the ${ }^{87} \mathrm{Sr} /{ }^{86} \mathrm{Sr}$ ratio for the measure standard was $0.710221 \pm 1 \times 10^{-6}$, which is the same to the theoretical value of the standard.

\section{RESULTS AND DISCSSION}

The barite deposits are restricted to a fairly limited stratigraphical range within the Late Jurassic rocks of units B and C (Marsis deposit) and of Late Cretaceous age (Lefan deposit); therefore, they are considered as strata-bound deposits

(Al-Ka'aby and Al-Azawi, 1992; Awadh, 2006). The analytical results of the analyzed four samples are listed in (Table 1).

Wang and Chu (1993) reported a group of $\mathrm{Sr}$ isotope data ranging from 0.708027 to 0.708810 based on the measurement of barite samples of Late Sinian to Early Cambrian in south China, which are lower than that of coeval seawater and marine carbonate, and as a consequence, they proposed that the sedimentation of the barite was closely related to submarine volcanic or hydrothermal activities.

The ${ }^{87} \mathrm{Sr} /{ }^{86} \mathrm{Sr}$ ratios in this work range between 0.708226 and 0.708452 , which are very close to each other and similar to those reported by Wang and Chu (1993). The ratios are higher than those of coeval seawater in marine carbonate of Late Cretaceous- Oligocene between 0.7073-0.7078 (Figs 3 and 4).

Fluid inclusion study carried out on one sample of Lefan barite deposit suggested that it occurred in an aqueous solution with salinity of $15.5 \mathrm{wt} \% \mathrm{NaCl}$ equiv. and formed at very low temperature ranging between $50^{\circ} \mathrm{C}$ to $60^{\circ} \mathrm{C}$ (Awadh, 2006).

The absence of any large scale $\mathrm{Pb}$ - $\mathrm{Zn}$ - fluorite mineralization in association with barite may rule out the possibility of its high temperature hydrothermal origin (Sharma et al., 2003). The presence of rose like shape in the barite deposits is another indication for the deposition at a low temperature (Ayhan, 2001; Paytan et al., 2002; Paradis et al., 2004).

Strontium isotope composition of seawater is mainly controlled by Sr from the crust and mantle (basalt). Strontium from the crust is principally provided by weathering of the ancient continental rocks, its ${ }^{87} \mathrm{Sr} /{ }^{86} \mathrm{Sr}$ ratio is comparatively high (average value 0.7119), because the materials from the crust are rich in $\mathrm{Rb}$ (Palmer and Edmond, 1989). While Sr from the mantle is mostly derived from mid-ocean ridge hydrothermal system, where ${ }^{87} \mathrm{Sr} /{ }^{86} \mathrm{Sr}$ ratio is comparatively low (average value 0.7035), due to the depleted of material from the mantle $\mathrm{Rb}$ (Palmer and Elderfield, 1985). The present- day average value of global seawater ${ }^{87} \mathrm{Sr} /{ }^{86} \mathrm{Sr}$ ratio is 0.70973 (Denison et al., 1994) as shown in Figure 4. Sr isotope composition and evolution of seawater are effected by such global events as the change of mid- ocean ridge hydrothermal system, the change of the global sea 
level and the global catastrophic events and so forth (Jones et al., 1994; Fei et al., 2004; Huang et al., 2004).

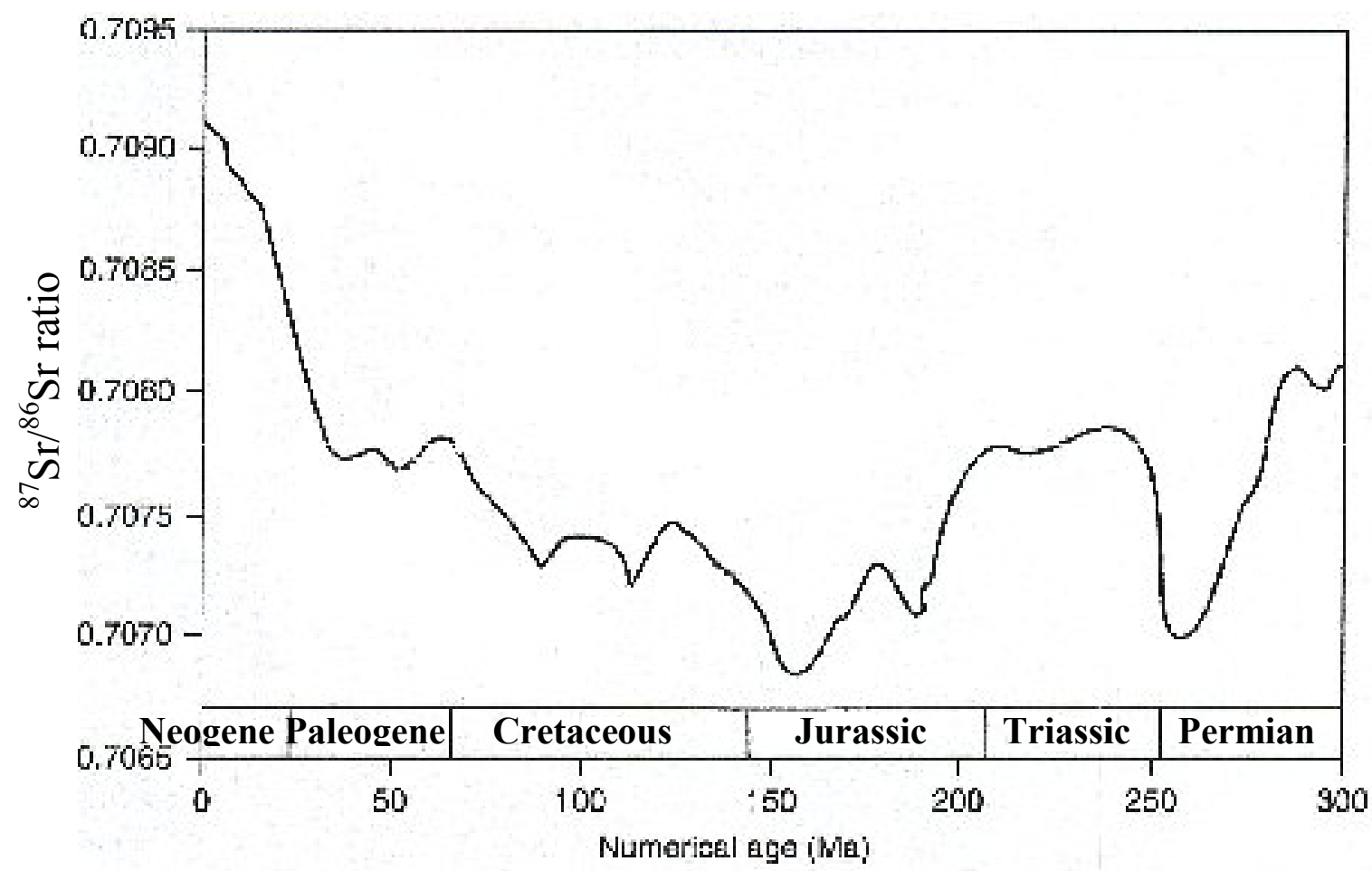

Fig. 3: Seawater (McArthur et al., 2001).

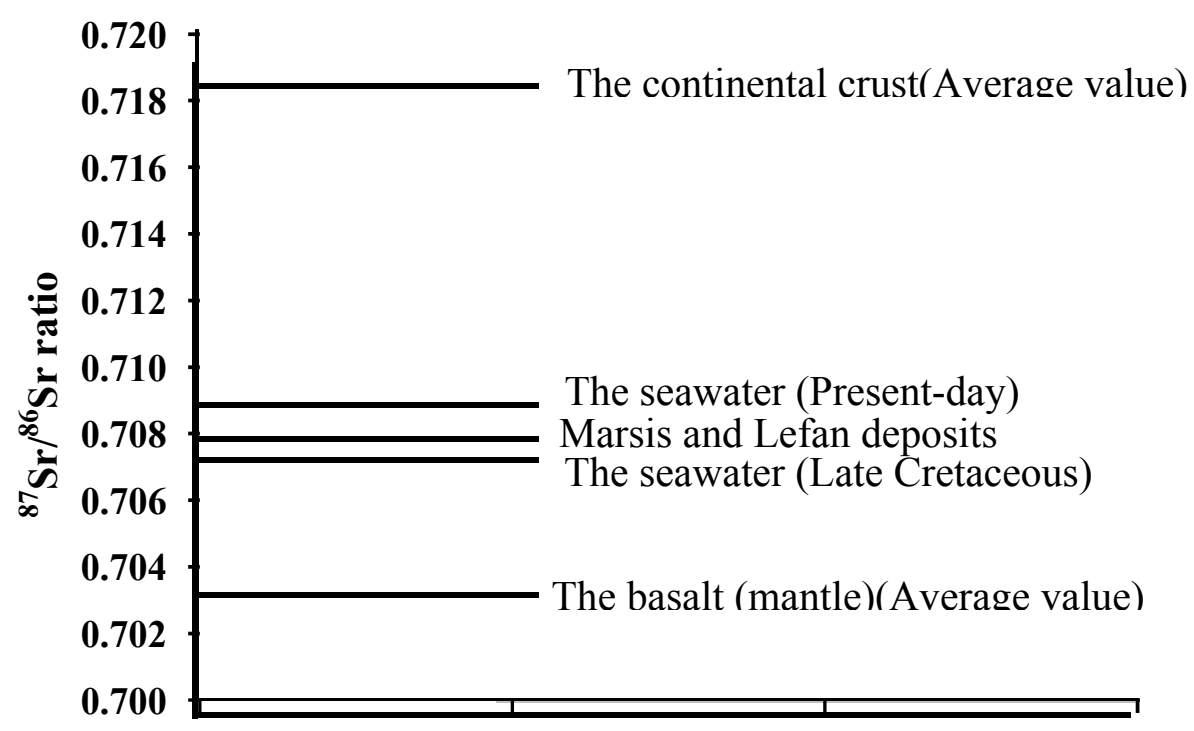

Fig.. 4: The Correlative Chart of Sr Isotope Composition of Different Barite Deposits, Rocks and Seawater (Modified from Fei et al., 2004). 
Therefore, $\mathrm{Sr}$ isotope composition and evolution of marine carbonate and sulphate, which did not experience diagenetic alteration, could reflect the composition of the coeval seawater and are important geochemical proxies for the global events. To certain extent, the $\mathrm{Sr}$ isotope composition of global seawater is homogeneous because the residence time of $\mathrm{Sr}$ in seawater (about $10^{6} \mathrm{a}$ ) is longer than that of global seawater circulation (Denison et al., 1994).

Fei et al. (2004) reported ${ }^{87} \mathrm{Sr} /{ }^{86} \mathrm{Sr}$ ratios of the layered barite deposits, from east Guizhou (China), between 0.708310 and 0.708976 which are lower than those of coeval marine carbonate of Early Cambrian (0.7090), showing that $\mathrm{Sr}$ with low ${ }^{87} \mathrm{Sr} /{ }^{86} \mathrm{Sr}$ ratios was from seafloor volcanic or hydrothermal activities. Suggesting that the $\mathrm{Sr}$ in barite is not all from seawater and partially might be from the mantle which have low ${ }^{87} \mathrm{Sr} /{ }^{86} \mathrm{Sr}$ ratio. While the two other samples from barite vein and nodule (east Guizhou) have higher ${ }^{87} \mathrm{~S} /{ }^{86} \mathrm{Sr}$ ratios $(0.709585$ and 0.709537$)$ than coeval marine carbonate, possibly is due to involvement of radiogenic terrigeneous source in sediments (Jones et al., 1994; Paytan et al., 2002).

From Late Cretaceous to Oligocene, the seawater ${ }^{87} \mathrm{Sr} /{ }^{86} \mathrm{Sr}$ ratio had been globally elevated than the Late Jurassic, and reached to 0.7078 by the Late Cretaceous (McArthur et al., 2001). Marsis and Lefan barite deposits were formed in Late Cretaceous. Awadh (2006) studied the sulfur isotopes of galena that associated with barite in Lefan area, and he concludes the age between Late Cretaceous and Oligocene. The barite ${ }^{87} \mathrm{Sr} /{ }^{86} \mathrm{Sr}$ ratios of these two deposits between 0.708226 and 0.708452 are higher than those of coeval seawater (Fig. 4). Suggesting that the $\mathrm{Sr}$ in barite is not all from seawater and partially might be from the terrigeneous source through water-rock interaction, and as a consequence, it is proposed that the Late Cretaceous barite deposits should be a product of the low temperature hydrothermal fluids. These fluids are ascending upward through the faults and fractures that may be related to episodic deformation of the rocks during Laramide Orogeny in the Late Cretaceous (Awadh, 2006).

\section{CONCLUSIONS}

The barite ${ }^{87} \mathrm{Sr} /{ }^{86} \mathrm{Sr}$ ratios of Marsis and Lefan deposits, between 0.708226 and 0.708452 , are similar to each other, which might have the same source and origin. These ratios are greater than those of coeval marine seawater of Late Cretaceous to Oligocene (0.7073- 0.7078), showing that the Sr in barite is not all from seawater but is partially from involvement of terrigeneous source sediments that interacts with the low temperature hydrothermal solutions that formed this deposits. The suggested age of these mineralization is Late Cretaceous or younger. 


\section{REFERENCES}

AL-Ka'aby, A. A. and Al-Azawi, A. M., 1992. The Detailed Investigations for Strata-Bound Barite Deposits in Marsis locality, North Zakho, Iraq, GEOSURV, Internal Report No. 2071, 95p. (in Arabic).

Awadh, S. M., 2006. Mineralogy, Geochemistry and Origin of the Lead-ZincBarite Deposits from Selected Areas from North of Zakho, Northern Iraq, University of Baghdad, Unpub. Ph.D. Thesis, Iraq, 191p.

Ayhan, A., 2001. Stratiform Barite Deposits between Sarkikaraagac (Isparta) and Huyuk (Konya) in Sultandag Region, Turkey Geochemistry, Vol. 61, pp. 54 - 66.

Ayuso, R. A., Kelley, K. D., Leach, D. L. and Young, L. E., 2004. Origin of Red Dog Zn-Pb-Ag Deposits, Brooks Range, Alaska: Evidence from Regional Pd and Sr Isotope Sources, Econ. Geol., Vol. 99, pp. 1533 - 1553.

Barbieri, M., Barbieri, M., Fidelibus, M. D. and Morotti, M., 1998. First Results of the Application of the Isotopic Ratio ${ }^{87} \mathrm{Sr} /{ }^{86} \mathrm{Sr}$ in the Characterization of Seawater Intrusion in the Coastal karstic Aquifer of Murgia (South Italy).

Bellen, R. C. Van, Dunnigton, H.V., Wetzel, R. and Morton, D. M., 1959. Lexique Stratigraphique International, Vol. III, Asie, Iraq, International Geology Congress Commission de Stratigraphique, Vol. 3, Fasco. 10a, 333p.

Denison, R. E., Koepnick, R. B. and Burke, W. H., 1994. Construction of Mississippian, Pennsylvanian and Permian Seawater ${ }^{87} \mathrm{Sr} /{ }^{86} \mathrm{Sr}$ Curve, Chem. Geol., Vol. 112, pp. 145 - 167.

Fei, X., Dongsheng, M., Jiayong, P. and Zhanxue, C., 2004. Strontium Isotopic Signature of Hydrothermal Sedimentation from Early Cambrian Barite Deposits in East Guizhou, China, Chinese Science Bulletin, Vol. 49, No.24, pp. 2632 - 2636.

Hall, A., 1987, Igneous Petrology, John Wiley and Sons, Inc., New York, 552p. Huang, S. J., Shi, H. and Shen, L. C., 2004. The Related Global Correlation of Evolution of Sr Isotope of the Late Cretaceous in Tibet, and Data Marine Sediments, Science in China, Series D.

Jassim, S. Z. and Goff, J. C., 2006. Geology of Iraq, Dolin, Prague and Moravian Museum, Brno, 318p.

Jones, C. E., Jenkins, H. C., Coi, A. L. and Hesselbo, S. P., 1994. Strontium Isotopic Variations in Jurassic and Cretaceous Seawater, Geochimica et Cosmochimica Acta, Vol. 58, No. 14, pp. 3061 - 3074.

McArthur, J. M., Howarth, R. J. and Bailey, T. R., 2001. Strontium Isotope Stratigraphy: LOWESS Version 3: Best Fit to the Marine Sr-Isotope Curve for 0-509 Ma and Accompanying look-Up Table for Deriving Numerical Age. Jour. Geol., Vol. 109, pp. 155 - 170.

McCarthy, M. J. and Smith, J. S., 1954. Geological Investigation for NE Zakho Region, National Company for Minerals, Iraq, Internal Report.

Ma'ala, k., Hassan, K. M. and Misconi, H., 1990. Detail Geological Survey of Sanat-Marsis Area, GEOSURV, Baghdad, Iraq, Internal Report 1979. 
Palmer, M. R. and Edmond, J. M., 1989. The Strontium Isotope Budget of the Modern Ocean, Earth Planet Sci. Lett., Vol. 92, pp. 11 - 26.

Palmer, M. R. and Elderfield, H., 1985. Sr Isotope Composition of Seawater Over the Past 75 Mys, Nature, Vol. 314, pp. 526 - 528.

Paradis, S., Chi, G. and Lavoie, D., 2004, Fluid Inclusions and Isotopes Evidence for the Origin of the Upton Ba- $\mathrm{Zn}-\mathrm{Pb}$ Deposits, Quebec Appalachians, Canada, Econ. Geol., Vol. 99, pp. 807 - 817.

Paytan, A., Mearon, S., Cobb, K. and Kastner, M., 2002. Origin of Marine Barite Deposits: Sr and S Isotope Characterization, Geology, Vol. 30, No. 8, pp.747 - 750 .

Sharma, R., Verma, P. and Sachan, H. K., 2003 Strontium Isotopic Constraints for the Origin of Barite Mineralization of Tons Valley, Lesser Himalaya, Current Science, Vol. 85, No. 5, pp. 653 - 656.

Wang, Z. C. and Chu, X. L., 1993, Sr Isotope of Barite and Witherite in Lower Cambrian in China, Chinese Science Bulletin, Vol. 38, No.16, pp. 1490 -1492. 